\title{
Effect of low-protein diets on the nitrogen balance and productivity of pigs
}

\author{
N.S.-A. Niyazov, K.S. Ostrenko*
}

Institute of Animal Physiology, Biochemistry and Nutrition - Branch of Ernst Federal Science Center for Animal Husbandry, Borovsk, Kaluga oblast, 249013, Russian Federation

*Corresponding author: Email- Ostrenkoks@gmail.com

Journal of Livestock Science (ISSN online 2277-6214) 11: 106-109

Received on 24/4/2020; Accepted on 30/6/2020

doi. 10.33259/JLivestSci.2020.106-109

\begin{abstract}
The purpose of this work was to establish the relationship between the effect of low-protein diets on nitrogen metabolism and productivity indicators for fattening young pigs. Low-protein diets are balanced by bioavailable essential amino acids. The efficiency of nutrient utilization and nitrogen excretion in the urine and feces of reared pigs was evaluated. The study was conducted on 3 groups of Landrace $\times$ great white pigs, 12 pigs each. Animals of group I (control) received complete feed with levels of components in growing period: crude protein (CP) - $172 \mathrm{~g}$, in group II, the crude protein level was reduced to $151 \mathrm{~g} / \mathrm{kg}$ in growing and to $142 \mathrm{~g} / \mathrm{kg}$ in finishing periods, and in group III - to 134 and $130 \mathrm{~g} / \mathrm{kg}$, respectively. The increase in body weight during the finish in groups 1 and 2 was approximately the same (40.62 and $40.28 \mathrm{~kg}, 752$ and $746 \mathrm{~g}$, respectively); in group 3, it was $6.2 \%$ less $(\mathrm{P}<0.05)$ than in the control group. The efficiency of feed nitrogen use in group 2 was higher by $6 \%$ compared to group 1, nitrogen excretion in groups 2 and 3 was reduced by 24.4 and $33.8 \%(P<0.05)$ in the urine and by 20.7 and $36.0 \%(\mathrm{P}<0.05)$ in the feces, respectively. The results of this study show that reducing the level of raw protein in the diet for rearing and refining pigs with the addition of synthetic essential amino acids reduces the release of nitrogen in the urine and feces, optimizing protein metabolism and rational use of feed proteins, contributing to increased productivity while reducing the cost of feed.
\end{abstract}

Key words: growing-finishing pigs; environmental pollution by nitrogen; low-protein diets; supplements of essential amino acids 


\section{Introduction}

The increasing risks of environmental pollution by nitrogen released from pig industry runoff compel researchers to explore the possibility to reduce protein level in diets for growing-finishing pigs. Studies on the scientific substantiation of the animal's requirements in essential amino acids, are important for the development of pork production technologies that reduce environmental pollution with nitrogen excreted by the animals in the urine and feces Kendall et al., (1999); Zervas \& Zijlstra, (2000); Figueroa et al., (2002); Otto et al., (2003); Ryadchikov, (2006); Niyazov \& Kal'nitskii, (2014). To ensure high productivity, animals require diets with a balanced composition of essential amino acids. On the other hand, it is impossible to reduce the quantity of "superfluous" amino acids entering the body beyond the need for maintaining the basic metabolism and growth, if the requirements of pigs in essential amino acids, including those assessed for their true availability for absorption in small intestine, are not known Otto et al., (2003); Fastinger \& Mahan, (2006); Stein et al., (2007). The aim of this work is to evaluate the effect of low-protein diets balanced by the bioavailabale essential amino acids, on the rate of growth, efficiency of nutrient utilization and nitrogen excretion with urine and feces in growing-finishing pigs.

\section{Material and methods}

The research was carried out on the basis of Vivarium Institute of Physiology, Biochemistry and Animal Nutrition - a branch of the Federal Scientific Center for Animal Husbandry. A. N. ernst, Borovsk, Kaluga region, Russian Federation, 55.12 '40.85" North 36.27 '26.03" East. The study was conducted in the spring and summer period. After the equalizing period, 36 crossbreed pigs (Landrace $\times$ Large White) were randomly divided into three groups, by 12 animals each. The experiment included two periods - growing and finishing. Pigs weighing were performed at the beginning of the experiment and at the end of each age period. The first period is from the age of 30 days to the age of 120 days. The finish period is from day 120 to day 210 .

Animals of group I (control) received complete feed with levels of components in growing period: crude protein (CP) and metabolizable energy (ME) - $172 \mathrm{~g}, 12.56 \mathrm{MJ}$ and limiting amino acids, g/kg feed: lysine - 7.7 (true available for absorption in the intestine- 588$)$, threonine - 4.83 (- 3.75), methionine - $4.73(-3.82)$, and in finishing period - $153 \mathrm{~g}, 12.34 \mathrm{MJ}, 5.75(-5,08), 4.5,(-3.49), 3.06,(-2.47) \mathrm{g} / \mathrm{kg}$, respectively. In group II, the crude protein level was reduced to $151 \mathrm{~g} / \mathrm{kg}$ in growing and to $142 \mathrm{~g} / \mathrm{kg}$ in finishing periods, and in group III - to 134 and $130 \mathrm{~g} / \mathrm{kg}$, respectively. The content of lysine, threonine and methionine in the diets of groups II and III in both periods was the same as in the control group, due to the addition of synthetic amino acids. In the course of the experiment, we controlled the consumption of feed, its chemical composition and consumption per unit of growth. To determine the assimilation of feed nitrogen and the effectiveness of its use, balance trial was carried out at the end of the growing period on three animals from each group. To characterize the metabolism of nitrogenous substances, the concentration of urea and creatinine; activity of aspartate aminotransferase, alanine aminotransferase, creatine kinase, alkaline phosphatase were determined in the blood plasma. The analysis of feed for the content of dry matter, crude protein, total amino acids, fat, crude fiber was carried out according to standard methods. Nitrogen content in urine and feces was determined according to Kjeldahl, on Kjeltek device.

\section{Results and discussion}

The data obtained on pigs fed diets with different levels of protein and essential amino acids, suggests that changes in the quantitative and qualitative amino acid composition of mixed feed had an ambiguous impact on the growth of animals and feed conversion.

The animals of the control group that received standard complete feed, at the end of growing period had the best values of live weight and daily live weight gains (LWG) (Table 1). In pigs of group II, in which the level of crude protein in feed was reduced to $151 \mathrm{~g} / \mathrm{kg}$ and synthetic amino acids have been added, there was no significant decrease in average daily LWG, and animals of this group consumed less crude protein (by $50.8 \mathrm{~g}$ ) per kg of LWG compared to control, which is a positive factor in this experiment.

The decrease in the level of crude protein to $130 \mathrm{~g} / \mathrm{kg}$ of feed (group III) with the addition of synthetic essential amino acids to the level of control group negatively affected the increase in LWG compared with control. In the studies of other authors Ryadchikov, (2006), it has been noted that a decrease in the protein level in the feed by $3.8 \%$ causes an imbalance of essential and non-essential amino acids, which adversely affects the productivity of animals Ryadchikov, (2006).

LWG and average LWG for the fattening period in the I and II groups were approximately the same (40.62 and $40.28 \mathrm{~kg}, 752$ and $746 \mathrm{~g}$, respectively), in the III group these indicators were $6.2 \%$ less $(\mathrm{P}<0,05)$ compared with the control group. Feed consumption per unit of LWG in group III was also higher compared with I and II groups. In animals of II and III groups, a decrease in the consumption of crude protein ( $\mathrm{g} / \mathrm{kg} \mathrm{LWG}$ ) was observed compared to control (by 6.3 and $10.1 \%$, respectively). 
The data obtained in the balance experiment confirm (Table 2) that a decrease in the level of crude protein with the addition of synthetic essential amino acids is an effective method of reducing nitrogen excretion. This decrease in nitrogen excretion with urine against the control group was $24.4 \%(\mathrm{P}<0.05)$ in group II and $33.8 \%$ $(\mathrm{P}<0.05)$ in group III, i.e. these groups excreted nitrogen by 3-4 g/day less compared with control. Pigs of these groups were also excreted with feces less - by 20.7 and $26.0 \%$ ( $\mathrm{P}<0.05)$ compared to control group.

Animals of the II group more effectively used nitrogen feed $\mathrm{t}=\mathrm{in}$ comparison with the animals of control group in terms of consumed (by $6.2 \%$ ) and digested nitrogen (by $6.0 \%$ ).

The increase in the digestibility of feed protein by pigs in group II, apparently, is due to the optimal content of true available essential amino acids in the feed. At the same time, the pigs of the control group excreted the largest quantity of nitrogen with urine, since they consumed more nitrogen in the feed, and an excessive amount of non-limiting amino acids absorbed in the intestine. In pigs of I and II groups the deposition of nitrogen was almost the same, despite the difference in the percent of nitrogen digested and excreted with urine. The reason for this, apparently, was the optimal supply of amino acids and energy in pigs of group II, while in the control group there was some excess of non-essential amino acids and energy.

Our experimental data are consistent with studies Tuitoek et al., (1997); Liu et al., (1999), in which the decrease in the concentration of crude protein by 2-3\% vs norm with the supplements of essential synthetic amino acids did not reduce the average daily LWG in pigs. On the other hand, in those papers Kendall et al (1999; Zervas \& Zijlstra, (2000), in which the concentration of crude protein in the diet was reduced by more than $3 \%$, a decrease in LWG, digestibility and nitrogen deposition in the body was indicated, despite the supplement of synthetic essential amino acids.

The decrease in the content of crude protein in the diet of pigs in group III from 172 to $134 \mathrm{~g}$ with the addition of synthetic amino acids in the same amount as in group II, provided a significant decrease in the total excretion of nitrogen with feces and urine $(\mathrm{P}<0.05)$ on the background of a $10 \%$ reduction in nitrogen deposition in this group.

In a study Otto et al., (2003), a decrease in the level of crude protein in the diet reduced the total loss of nitrogen, mainly due to its fecal excretion, on the background of slight decrease in nitrogen deposition in the body. However, this decrease in nitrogen deposition was not associated with a decrease in digestibility of non-limiting amino acids in the small intestine.

The coefficients of the apparent digestibility of lysine, threonine and methionine in the II and III groups were higher by 6-14\% compared with control group (Table 3). This can be explained by the fact that synthetic analogs of these amino acids, the availability of which is about $100 \%$, have been added to the diets of these groups. There were no significant inter-group differences on the coefficients of apparent digestibility of non-essential amino acids. The data on the apparent digestibility of total amino acids is generally consistent with the digestibility of nitrogen and crude protein in growing pigs Gomez et al., (2002).

The decrease in the concentration of crude protein in the diet of pigs of group III from 172 to $142 \mathrm{~g}$ with the addition of synthetic amino acids in the same amount as in group II, provided a significant decrease in the total excretion of nitrogen with feces and urine $(\mathrm{P}<0.05)$ and $10 \%$ decrease in nitrogen deposition in the body of pigs of this group.

The effectiveness of the use of amino acids in biosynthetic processes can be indirectly judged by changes in the concentration of urea in the blood plasma. The urea level in the pigs of I, II and III group was 5.21 \pm 0.49 ; $5.04 \pm 0.43$ and $5.67 \pm 0.04 \mathrm{mM}$ respectively $(\mathrm{n}=12)$. A lower concentration of urea in the blood plasma in group II, compared with group III, may be associated with more efficient use of amino acids for protein biosynthesis.

Because the low-protein diets in this experiment were balanced for essential amino acids, macro- and microelements and vitamins, significant intergroup differences were not revealed in total protein concentration, albumin, creatinine, activity of creatinine kinase, AST, ALT and alkaline phosphatase in blood plasma, and these parameters were within the physiological norm.

\section{Conclusion}

To reduce the excretion of nitrogen in growing-finishing pigs, the low-protein diets can be used with increased level of limiting amino acids lysine, threonine, methionine, taking into account the true availability_of these amino acids for absorption in small intestine. The decrease in protein level in the diet for Landras $\times$ Large White pigs to $151 \mathrm{~g} / \mathrm{kg}$ of feed during the growing and up to $142 \mathrm{~g} / \mathrm{kg}$ of feed during the finishing period with supplements of synthetic essential amino acids provides the decrease in nitrogen excretion with urine by $24.4-33.8 \%$ and by $20.7-26.0 \%$ with feces, does not adversely affect the increase in body weight gain and reduces the 
consumption of crude protein per unit of live weight gain. The results of this study indicate that reducing the level of crude protein in the diet for growing-finishing pigs with the addition of synthetic essential amino acids, reduces the flow of nitrogen into the environment with urine and feces, without adversely affecting productive performance indicators.

\section{References}

1) Fastinger, N.D., Mahan, D.C. (2006). Determination of the ileal amino acid and energy digestibilities of corn distillers dried grains with solubles using grower-finisher pigs. Journal of Animal Science, 84, 1722-1728.

2) Figueroa, J.L., Lewis, A.J., Miller, P.S., Fischer, R.L., Gomez, R.S., Diedrichsen, R.M. (2002). Nitrogen metabolism and growth performance of gilts fed standard corn-soybean meal diets or low-crude protein, amino acid-supplemented diets. Journal of Animal Science, 80: 2911-2919.

3) Gomez, R.S., Lewis, A.J., Miller, P.S., Chen, H.-Y. (2002). Growth performance, diet apparent digestibility, and plasma metabolite concentrations of barrows fed corn - soybean meal diets or low-protein, amino acid supplemented diets at different feeding levels. Journal of Animal Science, 80: 644-653.

4) Kendall, D. C., Richert, B. T., Sutton, A. L., Frank, J. W., De Camp, S. A., Bowers, K. A., Kelly, D., Cobb, M. (1999). Effects of fiber addition (10\% soybean hulls) to a reduced crude protein diet supplemented with synthetic amino acids verses a standard commercial diet on pig performance, pit composition, odor and ammonia levels in swine buildings. Journal of Animal Science, 77(Suppl.1), 176-184.

5) Liu, H., Allee, G.L., Berkemeyer, J.J., Touchette, K.J., Spencer, J.D., Kim, I.B. (1999). Effect of reducing protein level and adding amino acids on growth performance and carcass characteristics of finishing pigs. Journal of Animal Science, 77(Suppl. 1, 69-79.

6) Niyazov, N.S.-A., Kal'nitskii, B.D. (2014). Productivity and nitrogen metabolism in pigs fed low protein diets with different levels of essential amino acids. Reports of the Russian Academy of Agricultural Sciences, 5, 60-63 (in Russian)

7) Otto, E.R., Yokoyama, M., Ku, P.K., Ames, N.K., Trottier, N.L. (2003). Nitrogen balance and ileal amino acid digestibility in growing pigs fed diets reduced in protein concentration. Journal of Animal Science, 81, 1743 1753.

8) Tuitoek K., Young L.G., de Lange D.F.M., Kerr B.J. (1997). The effect of reducing excess dietary amino acids on growing-finishing pig performance: An evaluation of the ideal protein concept. Journal of Animal Science, 75, 1575-1583

9) Ryadchikov, V.G. (2006). Norms and diets for feeding farm animals: methodology, errors, perspectives. Agricultural Biology, 4, 68-81 (In Russian).

10) Stein. H.H., Sève, B., Fuller, M.F. et al. (2007). Invited review: Amino acid bioavailability and digestibility in pig feed ingredients: Terminology and application. Journal of Animal Science, 85, 172-180.

11) Zervas, S., Zijlstra, R.T. (2000). Effects of dietary protein and oat hull fiber on nitrogen excretion patterns and postprandial plasma urea profiles in growing pigs. Journal of Animal Science, 80, 3238-3246 